Masquerade Politics 



\title{
Masquerade Politics
}

Explorations in the Structure of Urban Cultural Movements

\author{
Abner Cohen
}

\section{University of California Press}

$$
\text { Berkeley / Los Angeles }
$$


University of California Press 1993

Berkeley and Los Angeles

Published in arrangement with Berg Publishers Limited, Oxford, England

Berg Publishers Limited

Editorial Offices:

165 Taber Avenue, Providence, RI 02906, USA

150 Cowley Road, Oxford, OX4 1JJ, UK

(C) Abner Cohen 1993

All rights reserved.

No part of this publication may be reproduced in any form

or by any means without the written permission of

the publishers.

Library of Congress Cataloging-in-Publication Data

Cohen, Abner.

Masquerade politics : explorations in the structure of urban cultural movements / Abner Cohen.

p. $\mathrm{cm}$.

Includes bibliographical references and index.

ISBN 0-520-07838-1 (alk. paper)

1. Carnival-England-London-Political aspects. 2. West

Indians-England-London. 3. Notting Hill (London, England)

4. Festivals-Political aspects. I. Title.

GT4244.L66C64 1993

$394.2 ' 5-\mathrm{dc} 20$

Printed in the United States by Edwards Brothers, Ann Arbor, Mich. 
FOR S IMON

Artist \& musician 
